\title{
Employees Perceptions of Human Resource Management System and Practices Impact on Affective Commitment: Considering Mediating Role of Line Manager
}

\author{
ADEEL JAVED \\ $\mathrm{PhD}$ Scholar/Lecturer, Department of Management Sciences, \\ COMSATS University Islamabad, Pakistan. \\ Email: adeel_423@yahoo.com \\ Dr. OSMAN SADIQ PARACHA \\ Assistant Professor, Department of Management Sciences, \\ COMSATS University Islamabad, Pakistan.
}

\begin{abstract}
The purpose of this paper is to analyse the impact of employee's perception of HRM system strength and high performance work practices based on ability enhancing, motivation focused and opportunity creating practices on affective commitment. Furthermore, this paper explores the mediation effect of the line manager's ability, motivation, and opportunity to implement human resource practices between the high performance work practices, perception of HRM system strength, and affective commitment. This study is based on a quantitative research design. Data collected from 761 bank employees from different branches of private banks in Pakistan. A structural equational modeling technique was used to analyse the data. The result supported the positive impact of ability, motivation, and opportunity enhancing high performance work practices and HRM system strength on affective commitment. However, the mediation results indicated partial acceptance. The findings of this paper are expected to encourage researchers to be more thoughtful about the connection between these variables.
\end{abstract}

Keywords: High Performance Work Practices, HRM System Strength, Line Manager Role, AMO Framework, SHRM Practices.

\section{Introduction}

Recently, Human resource Management (HRM) researchers have sought to explain the association between human resource practices, HRM system strength and employee's outcomes (Cafferkey et al., 2019; Shin et al., 2020). The main aim of these researches is to bring back the opinions and reactions of individual employees to the Human resource Management system (Heffernan \& Dundon, 2016). The employee outcome is seen as a strategic opportunity and high performance work practices (HPWPs) are viewed as crucial factors for efficient employee outcomes. (Karman, 2020). The significant proposition is that Human resource Management practices bundles are the source of competitive advantage for organizations instead of individual practices (Kepes \& Delery, 2008). Based on ability, motivation and opportuity (AMO) theory, this study divided HPWPs into three coherent bundles these are, ability enhancing, motivation focused and opportunity creating practices.

HRM system, includes distinctiveness, consistency, and consensus (Bowen \& Ostroff , 2004). These attributes make a strong workplace climate, transform as employees ' mutual views of strategies, processes, routines, and incentives (Bowen \& Ostroff 2004). According to this view, the HRM system is used to 
assess the inherent signals and communication among employees which are enabled by HRM practice. When workers view HR practices as unique, systematic, and these procedures are adopted in a coherent manner by policy makers, person views are likely to intensify and move towards collectivism and ultimately lead towards affective commitment (Andersén \& Andersén, 2019). Since focusing on the affective commitment scholars found that affective commitment predicts desired employee actions, i.e. described as an emotional attachment to the company as well as an origin of good relationship with the organization (Andersén \& Andersén, 2019; Shin et al., 2020). Employee affective commitment is a proximal outcome of employee attitude and used as a dependent variable in this study ( $\mathrm{Ng} \&$ Feldman, 2011).

Previous research in organization studies exhibits a positive and well established association between HPWPs, HRM system and outcomes, in the manufacturing setting (Boselie, 2010). Recently, HRM systems and indivdual outcome relationships including different mediators have also extended to the service sector and depict a conducive environment facilitated by HRM systems (Boxall et al., 2011). There is an increasing trend of observing the line manger's participation in the implementation of HRM practices (Bayo-Moriones \& Bello-Pindado, 2021). Previous literature have recognized the importance of line manager participation in employee wellbeing and motivation (Bos-Nehles et al., 2013). In devolution literature the line managers has to enforce HR practices with other work responsibilities (Harris et al., 2002). Line managers are reluctant and hesitant in terms of capability and motivation to take on those responsibilities (Hope et al., 2005). The main concern in literature is whether line manager's participation help employee attitudes or not.Previous findings on this subject have mixed results. Some found positive outcomes (Azmi, 2010), while other failed to find the positive impact on employee's outcomes in sharing of responsibilities between line and HR manager (Renwick, 2003). This concept is based on AMO theory to clarify how line managers effectively enforce HR practices. Extending the previous work done by BosNehles et al., (2013), we also predict that the effectiveness of implementation of HRM practices by line manager will depend on the ability of line manger to apply these practices.Further more the opporuinty and motivation of line manager will enhance this effect. Based on these arguments, this study examine the medaiting role of ability, motivation, and opportunity of line managers to implementing HRM practives in the relationship between HPWPs (AMO), HRM system strength and affective commitment in developing coutry context i.e. Pakistan.

The reason for selecting the developing country context is that in recent decades, interest in the HPWPs, HRM system and role of line managers in in implementing HR practices has increased, as it has become a prominent phenomenon in Europe, the United States, and other developing countries (Conway \& Monks, 2010; Perry \& Kulik, 2008). Bjorkman et al. (2012)) argued that international HRM involve same practices as domestic but the complexity increases due to the cultural diversity and workforce diversity. The Pakistani culture is characterized as collective, with large power; the status of these groups is mainly concerned with a collectivist nature and social dynamics (Khilji, 2010). Furthermore, culture-bound factor's influence on HRM vary between regions to region. The lack of availability of the relevant published literature in Pakistan can be a strong starting point for our study.

Thus, this study differs from previous researches in the following respects. Firstly, this research extends existing understanding by exploring pathways for relationship involved in between HPWPs and HRM system strength on employee attitude outcome i.e affective commitment, especially in a developing country. Secondly, few researchers discussed that the HPWPs association is thought to be more noticeable in the manufacturing sectors (Chi, 2019). However, HPWPs create ability and motivation among employees to get themselves adapt to the uncertainty and flexibility of the service sector (Chuang \& Liao, 2010). This paper utilizes research into the HPWPs and the strength of the HRM system with more emphasis on specific sector orientations (Chi, 2019), particularly in the Pakistani context by drawing on a wide array of employee experiences. Finally, this study takes the contextual factors into account to help advance further HRM research. By researching in a Pakistani context, the research addresses the mechanism of signaling, communicating employees from different cultural settings. 


\section{Literature Review}

\section{High-Performance Work Practices and Affective Commitment}

HPWPs aim to enhance employee knowledge, skills, commitment and efficiency (Bos-Nehles \& Bondarouk, 2019). Based on the theoretical aspects from organizational psychology social exchange theory (Blau, 1964) and high performance work system (HPWS) theory (Boxall \& Purcell, 2011), this research pays attention to HPWPs relationship with employees outcome. Moreover, high performance work system (HPWS) theory (Boxall \& Purcell, 2011) provides an understanding of how HPWPs affect attitudes and behaviors of employees. The reason for selecting the HR Practices Group (Ability, Incentive and Opportunity) in this research study is based on the work of Jiang et al., (2012). Although global SHRM researchers have adopted this method to uncover the connection between HPWS and the outcome of their employees, it's been used modestly in SHRM literature in Pakistan.

As in other developed and developing countries banking industry is the main player in Pakistan's economy. Effective HRM practices are one of the critical factor for profitable banking operation, it also contributes to the development of innovative banking products and improved customer care (Aktar, 2018). Effective SHRM practises are one of the most significant considerations for regulating employee retention and satisfaction, especially in the Pakistani bank sectors (Bhatti \& Qureshi, 2007). One of the important indicators of employee positive attitude in the Pakistani banking sector is the emerging effective HRM system (Khan et al., 2015).

Previous study has shown a positive effect of work practices on employee, for example Alkhazali et al., (2020) found positive relationship between empowerment, HRM practices and employee outcomes in Jordanian banks. Similarly, Dayarathna, (2019) examine the impact of HPWS on employees effectiveness in Srilankan's banks and found positive correlation. Moreover, Ahmed \& Shin, (2019), argued that performance appraisal, selection and recruitment, and compensation HRM practices are positively related with indivdual employee outcomes, in Bangladeshi Banks. In an another research carried out by Chompukum (2012) on Thailand commercial banks, found training and employee relation HRM practices has impact on employees attitude. Summarising, previous studies specifically indicates that HRM practises have a positive impact on individual employee outcomes (Hussain \& Shahzad, 2014).

The social exchange theory (Blau, 1964) indicates that the implementation of HPWPs sends signals to express the concerns of the organization about the development of employees. Likewise the positive perception of employees about HPWPs is likely to reciprocate in their behavior, in shape of commitment to organization (Cole et al., 2002). Previous studies have shown positive impact of HPWPs on employee's outcomes; however, while few research studies suggested that HPWPs may have negative impact on employee's outcomes (Kroon et al., 2009). According to Van et al., (2012), HPWPs might have negative affect on employee health well-being, but it has positive influence on employee's happiness well-being and this happiness wellbeing leads to the employee affective commitment. Consequently, on the basis of this review, we can hypothesize that,

Hypothesis 1: Ability enhancing (H1a), motivation focused (H1b) and opportunity creating HPWPs (H1c) are positively related to employee affective commitment.

\section{HRM System Strength and Affective Commitment}

This research examine the strength of the HRM system as an effective and efficient means of communicating to workers what an organization expects, appreciates, and rewards (Ostroff \& Bowen, 2016). Based on the principle of co-variation of attribution by Kelley (1973), the strength of the HRM system consists of three features; (1) distinctiveness (HRM practises are visible, comprehensible and practically relevant to employees productivity). (2) Consistency (i.e. internally consistent uniform 
communication of HRM practices) and (3) consensus (i.e. general agreement on the intent of HR practices).In a strong situation, the above mentioned three features of HRM system strength can be viewed as the way of evaluating the inherent signaling and communicating mechanism implied through HR practices.

HRM system is viewed as highly recognizable, consistent by workers and when there is unity between stakeholders, it motivates them to change desired attitudes and behaviors, which in turn help them, meet the strategic goals of the company (Bowen \& Ostroff, 2004). In this paper we believe the affective commitment to the organisation is one of the employees' preferred behaviors. Prior research reviews have contradictory findings on strength of the HRM system and employee affective commitment. (Li et al., 2011; Sanders et al., 2008). One of Sanders et al. (2008) analysis found a positive correlation (with the exception of consensus), between distinctiveness, consistency and affective commitment. Though Ostroff \& Bowen (2016) have suggested that consensus is the necessary condition for others components of the HRM system. Li et al. (2011) also found contradictions in relationships as distinctive characteristics were considered essential for employee performance, whereas consistency was positively related to the intention to quit. Analysis on the effectiveness of the HRM system shows that it is still in its early stages due to limited empirical investigation and lack of theoretical understanding (Ostroff \& Bowen, 2016). This article reflects the key effects of HRM system strength on the affective commitment of employees. ; continuing Delmotte's et al. (2012), direction i.e. addressing perceptions of the strength of the HRM system. This can make the HR system reliable as agreed to and interpreted by employees. Following the lead of Ostroff $\&$ Bowen (2016), we hypothesize that:

Hypothesis 2: Employees perception of HRM systems as being distinctive (H2a), consistent (H2b), and consensus $(\mathrm{H} 2 \mathrm{c})$, have positive relationship with employee affective commitment.

\section{The Mediating Role of Line Manager}

Line managers need HRM-related expertise and abilities to effectively incorporate HRM practices in the department. Line managers need detailed knowledge of HRM, including legal requirements, in the absence of such knowledge and limited management experience, along with the information needed, which can create difficulty to fulfill their job responsibilities (Bos-Nehles et al., 2019).

Inadequate skills of managers in HRM hurt effectiveness (Trullen et al, 2016), because of lack of knowledge, line managerial skills related to the implementation of HRM are in-satisfactory and thus affect the effectiveness of line managers. Ability is a critical requirement for performing HRM tasks efficiently. Motivation is defined as the motivation and willingness of the line manager to perform HRM tasks in this field (Harris et al., 2002). Some managers, however, are optimistic about their HRM duties, others feel they are burdened with reticence by these roles.

This study posits that active HR engagement of line managers improves HR effectiveness by creating a situation where HR processes provide distinctive, consistent, and consensus-enhancing messages to employees. First, the presence of line managers in HR will improve an organization's HR practice distinguish ability. In the eyes of employees, this visibility of HR practices is crucial to the achievement of a high degree of HR effectiveness in organizations (Bowen \& Ostroff 2004). Second, line managers conducting HR tasks can boost the understanding of HR coherence as employees can see immediate connections between behavior patterns and corresponding incentives. Third, the consensus among team members may also be improved by letting line managers implement HR practices. Gittell (2001) suggested that line managers would have a greater effect on Group interactions if they are able to provide close and direct guidance to subordinates.

Rimi et al., (2017) conducted a study in commercial banks in Bangladesh, and found that both HRM manager and line manager play a critical role in the improvement of employees attitude and which in turn 
improves service quality in banks. Dany et al., (2008), provide new insights about the integration of HRM integration and employee outocme in banking sector. Similar results were found by Afiouni, (2007) in a research on Lebanese banks, that the bank's strategy is ineffective in term of employee reaction, in absence of proper implementation of HRM practices by HR and Line manager. Likewise, Liu et al., (2007) also support the role of line manager in effective implementation of HRM practices in service sector like banks. Ostroff \& Bowen (2016) have further stressed that there have been inconsistent research findings as the mediator between HRM strength and outcomes for employees. The concern that has recently been raised in the workers ' perception of effectiveness of their HR process and affective commitment literature is that within a particular working group environment participants manipulate each other's views about HRpractices (Kehoe \& Wright, 2013), as well as effect each other levels of affective commitment (Gardner, Wright \& Moynihan, 2011).Employees working within a working group in a certain HR environment are encouraged to share their opinions and feelings on these issues and establish what was called HR system's perceptions and mutual affective engagement (Kehoe \& Wright, 2013). There is, thus, a possibility of reciprocal gains in which both the individual and the organization can advance their well-being. The relation between expectations of the effectiveness of the ability, motivation, and opportunity of the line manager's to implement HRM practices, HPWPs, and the affective commitment should therefore be further examined. Based on the above observations, the current research is intended to discuss the above relationships and leads to the following hypothesis

Hypothesis 03: Ability, motivation, and opportunity of the line manager are to implement HRM practices mediate the relationship between ability-enhancing $(\mathrm{H} 3 \mathrm{a})$, motivation focused $(\mathrm{H} 3 \mathrm{~b})$ and opportunity creating HPWPs (H3c) and employee affective commitment.

Hypothesis 04: Ability, motivation, and opportunity of the line manager are to implement HRM practices mediate the relationship between distinctive (H4a), consistent $(\mathrm{H} 4 \mathrm{~b})$, and consensus (H4c) HRM system strength and employee affective commitment.

High performance work practices

Ability Enhancing HPWPs

Motivation Focused HPWPs

Opportunity Creating HPWPs

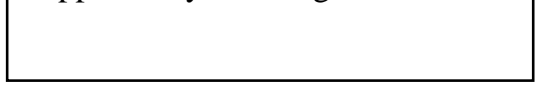

HRM System Strength

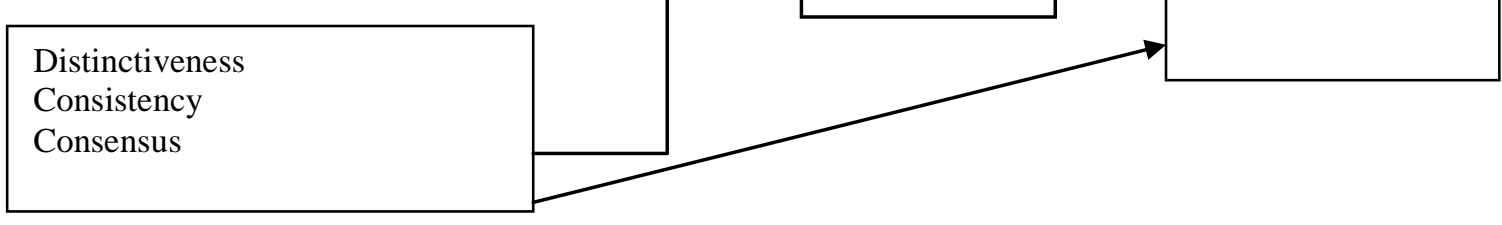

Figure 01: Conceptual Model

\section{Research Methodology}

\section{Data, Method, Samples, and Procedures}

The study is based on quantitative research technique, based on paper based survey design. This study employed the structural equation modeling technique (SEM) using M-Plus software to analyze the hypothesized relationships. Therefore, to obtain an immense illustration of the whole population, seven private commercial banks were selected for this study with a nationwide branch network as shown in table 
1. The selection of banks was from the large, medium and small sized banks groups, and is based on banking survey of Pakistan. A survey was conducted from different bank branches located in karcahi, Lahore, Peshawar, Abbottabad, Rawalpindi and Islamabad. The total number of employees in these seven large, medium, and small size private commercial banks are 69000 as per their annual reports, the details are shown in table 1 . Which represents more than $60 \%$ of total banking population. Based on simple random sampling technique 2100 surveys were distributed among bank employees working in these banks. For all branches, 792 responses were received 761 valid responses of employees were collected (response rate $36 \%$ ). The repsonses comprised of $77 \%$ males and 33\% females; more than $65 \%$ have tertiary education and in the age bracket of 31 there were $62 \%$ of respondents, while $47 \%$ have more than 5 years of experience.

Table 1: Number of Employees for selected banks

\begin{tabular}{|lccc|}
\hline Banks & Legend & Branches & Employees \\
\hline Habib Bank Limited & HBL & 1,716 & 15000 \\
United Bank Limited & UBL & 1,330 & 10500 \\
MCB Bank Limited & MCB & 1,257 & 10600 \\
Allied Bank Limited & ABL & 1,050 & 10000 \\
Bank Alfalah Limited & BAF & 653 & 7000 \\
Bank Al-Habib Limited & BAH & 661 & 9415 \\
Askari Bank Limited & Askari & 424 & 6,591 \\
Total & & 7091 & 69106 \\
\hline
\end{tabular}

\section{Measures}

All measures were quantified by using a one to five Likert scale, ( 1 being strongly disagree, and 5 being strongly agree). High performance work practices (HPWPs) was measured using scale from Obeidat et al., (2016), based on three dimension of HPWPs. Ability enhancing HPWPs was measured using 10 items, motivation focused HPWPs (14 items) and the last opportunity creating HPWPs (10 items). Ability of line manager to implement HR practices was measured on the occupational self-efficacy scale of Schyns and von Collani (2002) comprised of four items. Whereas line manager's motivation was measured with situational motivation scale of Guay et al. (2000), consisted of four items. Opportunity was operationalized by role overload scale of Reilly (1982) based on five items. The HRM system strength measure was adopted from Delmotte, Winne \& Sels (2012), based on three dimensions distinctiveness ( six items), consistency ( six items), consensus scale had four items. Employee affective commitment was measured by using a 5item scale developed by Allen \& Meyer (1990). Options for responses ranged from 1= much worse to $5=$ much better.

\section{Preliminary Analysis}

The various measurements were self-reported and obtained at one time. Though the questionnaires designed were anonymous and items of all constructs were arranged in a separate section of the questionnaire (Galbreath \& Shum, 2012), still, we cannot ignore the possibility of common method variance (CMV) bias. To investigate the impact of potential common variance this study used the the unmeasured latent methods factor test (Podsakoff et al., 2003) and confirmatory factor analysis (CFA) method (Williams et al., 2010). The common method variance factor, included indicators for all major constructs and calculated the degree to which the variance of each indicator was explained by its key construct and the common method variance factor. The results showed that the loadings of the method factor were insignificant and that the substantive variances of the indicators were significantly greater than the variances of their methods. An evaluation of the various items found that the measures identified four distinct variables. The result of CFA showed that no one-factor model fit the data that is $(\chi 26171.239$; $\mathrm{df}=$ $523 ; \chi 2 / \mathrm{df}=11.81, \mathrm{TLI}=.57, \mathrm{CFI}=.59, \mathrm{RMSEA}=.12, \mathrm{SRMR}=.07)$, which specified that there is no 
serious common variance method bias existed in the study. Both these tests suggested that CMV bias is not a serious concern and thus it is implausible to impact the results of the analyses that followed.

\section{Results}

Furthermore to test construct validity, we implemented a confirmatory factor analysis (CFA) before testing the hypothesis. The measurement model consisted of four variables; ability enhancing, motivation focused and opportunity creating HPWPs, employee perception of HRM system, line managers AMO and employee affective commitment .The results in table 2 indicated that the one-factor measurement model fit the data poorly, $6171.239 ; \mathrm{df}=523 ; \chi 2 / \mathrm{df}=11.81, \mathrm{TLI}=.57, \mathrm{CFI}=.59, \mathrm{RMSEA}=.12$; standardized root mean square residual $[\mathrm{SRMR}]=.07$. The three factor measurement model also demonstrated not so good fit with the data, $\chi 2=2224 ; \mathrm{df}=695 ; \chi 2 / \mathrm{df}=3.2 ; \mathrm{CFI}=.886 ; \mathrm{TLI}=.892 ; \mathrm{RMSEA}=.078 ; \mathrm{SRMR}=.067)$. 5 -factor measurement model to the data was a bit good $[\chi 2 /$ degrees of freedom $(\mathrm{df})=1.781,(\mathrm{TLI})=0.901$, $(\mathrm{CFI})=0.902(\mathrm{RMSEA})=0.055, \mathrm{SRMR}=.052]$. By contrast, the hypothesised eight-factor measurement model (including first order construct's factors of second order construct) demonstrated a very good fit with the data, $\left(\chi^{2}=2108 ; \mathrm{df}=701 ; \chi 2 / \mathrm{df}=3.0 ; \mathrm{CFI}=.933 ; \mathrm{TLI}=.943 ; \mathrm{RMSEA}=.08 ; \mathrm{SRMR}=.031\right)$. The results revealed that all the alternative models fit the data significantly worse than the eight-factor model.

Table 2: Measurement Model Fit Indices

\begin{tabular}{|lccccccc|}
\hline Model & $\boldsymbol{\chi 2}$ & $\mathbf{d f}$ & $\boldsymbol{\chi 2} / \mathbf{d f}$ & CFI & TLI & RMSEA & SRMR \\
\hline 8 Factor Model & 2108.317 & 701 & 3.0 & 0.933 & 0.943 & 0.08 & 0.031 \\
5 Factor Model & 2198.31 & 698 & 3.14 & 0.902 & 0.901 & 0.055 & 0.052 \\
3 Factor Model & 2224.25 & 695 & 3.2 & 0.886 & 0.892 & 0.078 & 0.067 \\
1 Factor Model & 6171.239 & 523 & 11.81 & 0.59 & 0.57 & 0.11 & 0.07 \\
\hline
\end{tabular}

Table 3, presents all the alpha coefficients, composite reliability estimates, and average variance extracted (AVE) values. As shown all these values were above their cutoff values of $0.7,0.7$, and 0.5 , respectively (Hair et al. 2016). To measure convergent validity, factor loadings of each items was measured for their respective constructs. All item loadings were above the threshold value of 0.7 , except for three items from the HPWPs (0.480) \& two items from the HRM system strength (0.492 and 0.578). Owing to their weak loadings, these five items were removed from further analysis. Previously mentioned HPWPs and HRM system strength was taken as second-order constructs in this study. CR and AVE of HPWPs were (0.928 and 0.589) and of HRM System construct equaled (0.948 and0.557), respectively, providing evidence of reliable second-order constructs.

Table 4 presents the standard deviations, mean, and correlations values for the factors. As shown in the table 4 all the variables were positively correlated with each other. For hypotheses 1, 2, 3, and 4 testing structural equation modeling (SEM) was applied using M-Plus version 7.3. This study uses SEM to test hypotheses which require many simultaneous correlations between latent variables and differentiate between direct and indirect effects, thus taking into account the errors in the multi-item build measurement. Hypothesis 1A, 1B, and 1C proposed that HPWPs based on AMO would be positively related to employee affective commitment. Table 5 shows that the HPWPs (AMO) impact on employee affective commitment were supported for (A) ability enhancing HPWP, $(b=.298, p<.001)(B)$ motivation $(b=.242, p<.001)$ and $(\mathrm{C})$ opportunity enhancing HPWP $(\mathrm{b}=.211, \mathrm{p}<.001)$. Hence, supported hypotheses $1 \mathrm{~A}, 1 \mathrm{~B}$, and $1 \mathrm{C}$.

Hypothesis 2A, 2B and 2C stated that employee's perception of HRM system strength would be positively related to employee affective commitment. Results displayed in Table 5 indicated that the impact of HRM system strength on employee affective commitment is significant and positive i.e. distinctiveness $(b=.387$, $\mathrm{p}<.004)$, consistency $(\mathrm{b}=.444, \mathrm{p}<.001)$ and consensus $(\mathrm{b}=.256, \mathrm{p}<.001)$, hence proved the hypothesis $2 \mathrm{~A}, 2 \mathrm{~B}$ and $2 \mathrm{C}$. 
Table 3 : Psychometric Properties of the Constructs

\begin{tabular}{|llll|}
\hline Variable & $\begin{array}{l}\text { Cronbach's } \\
\text { Alpha }\end{array}$ & $\begin{array}{l}\text { Composite } \\
\text { Reliability }\end{array}$ & AVE \\
\hline Ability Enhancing HPWPs* & 0.839 & 0.887 & 0.613 \\
\hline Motivation Focused HPWPs* & 0.842 & 0.862 & 0.611 \\
\hline Opportunity creating HPWPs* & 0.877 & 0.897 & 0.601 \\
\hline HPWPs & 0.824 & 0.866 & 0.599 \\
\hline Distinctiveness ** & 0.848 & 0.891 & 0.620 \\
\hline Consistency ** & 0.834 & 0.878 & 0.652 \\
\hline Consensus ** & 0.882 & 0.901 & 0.611 \\
\hline HRM System Strength & 0.818 & 0.846 & 0.602 \\
\hline Line Manager's AMO & 0.882 & 0.889 & 0.641 \\
\hline Employee Affective Commitment & 0.828 & 0.890 & 0.634 \\
\hline
\end{tabular}

HPWPs $=$ High performance work practices

**First-order constructs of the second-order HRM System Strength.

*First-order constructs of the second-order HPWPs.

H3 hypothesized that the line manager's AMO mediates the relationship between Ability enhancing (H3a), Motivation focused (H3b) and Opportunity creating HPWPs (H3c) and employee affective commitment. The study adopted the methods for the testing of mediation suggested by Preacher \& Hayes (2008). In order to measure mediation, we first analysed the effect of the predictor on the mediator and the outcome, and the mediator on the outcome after accounting for the predictor. Results indicated in table 5 that Ability enhancing (H3a), Motivation focused (H3b) and Opportunity creating HPWPs (H3c) was also positively related to the mediator line manager's AMO $(b=.172, .196$ and .221 respectively, $p<0.05)$. The line manager's AMO, had also a significant relationship with affective commitment of employee $(b=.439, p<$ $0.01)$.

Table 4 Correlations among Constructs

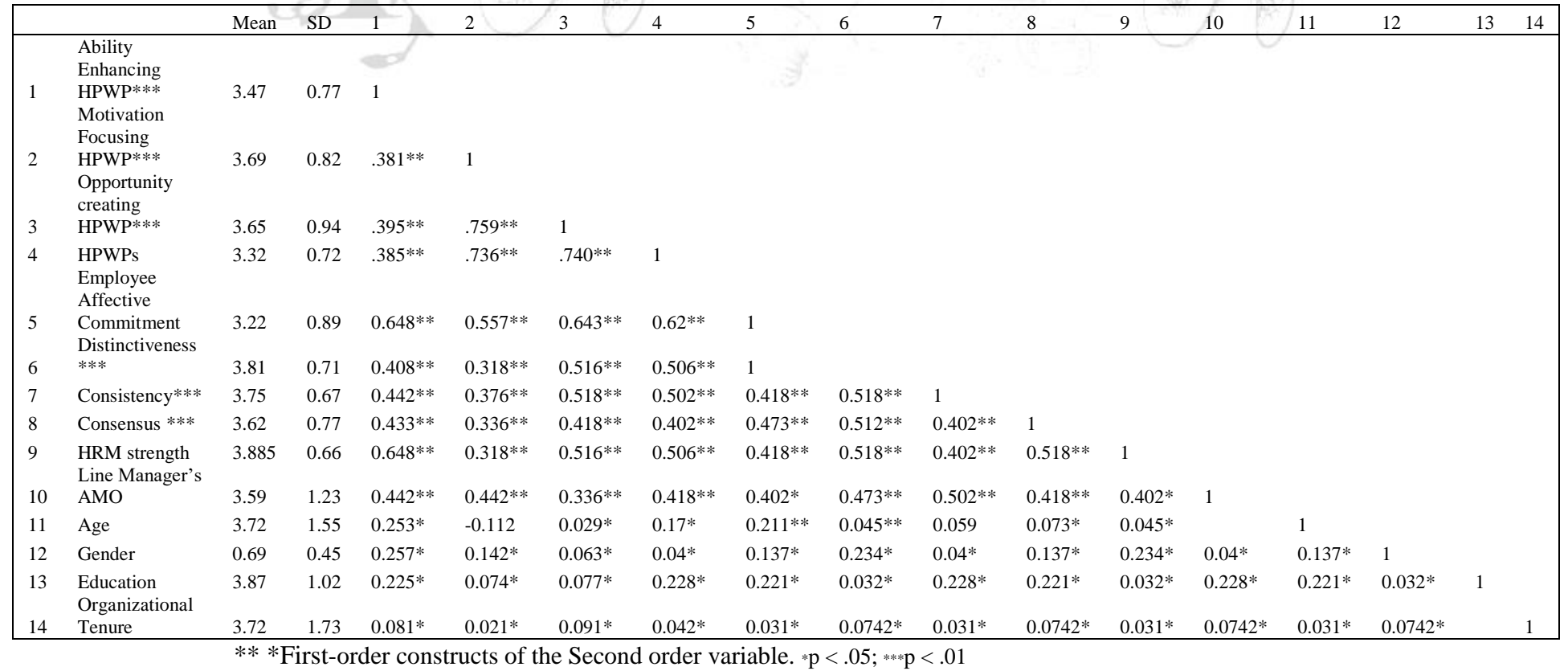




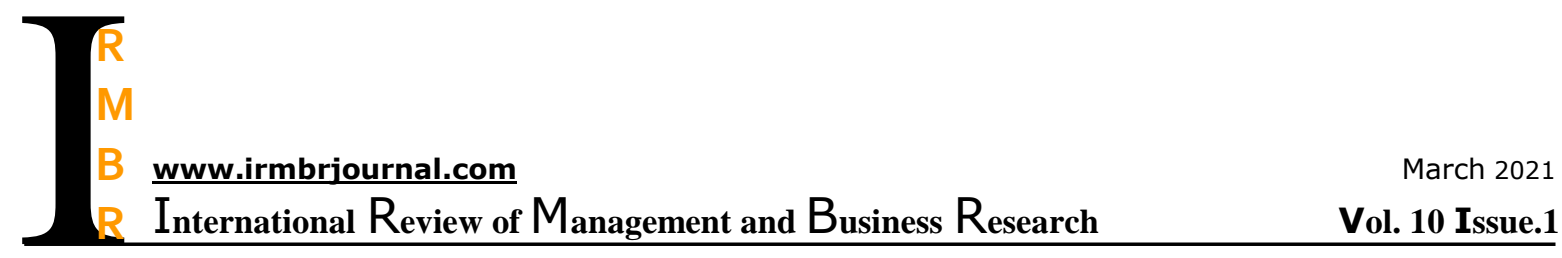

Table 5 Hypotheses Results

\begin{tabular}{|c|c|c|c|c|c|c|}
\hline Relationship & $\begin{array}{l}\text { Path } \\
\text { coefficient }\end{array}$ & $\begin{array}{c}\text { Std } \\
\text { Error }\end{array}$ & $\begin{array}{c}\mathbf{T} \\
\text { values }\end{array}$ & p-value & LCI & UCI \\
\hline $\begin{array}{l}\text { Ability Enhancing HPWPs } \rightarrow \text { Employee affective } \\
\text { commitment }\end{array}$ & 0.298 & 0.021 & 14.1 & $0.00 * *$ & 0.086 & 0.125 \\
\hline $\begin{array}{l}\text { Motivation Focusing HPWPs } \rightarrow \text { Employee affective } \\
\text { commitment }\end{array}$ & 0.242 & 0.033 & 7.33 & $0.00 * *$ & 0.067 & 0.128 \\
\hline $\begin{array}{l}\text { Opportunity Creating HPWPs } \rightarrow \text { Employee affective } \\
\text { commitment }\end{array}$ & 0.211 & 0.019 & 11.1 & $0.00 * *$ & 0.093 & 0.241 \\
\hline Distinctiveness $\rightarrow$ Employee affective commitment & 0.387 & 0.087 & 4.45 & $0.04 *$ & 0.432 & 0.596 \\
\hline Consistency $\rightarrow$ Employee affective commitment & 0.444 & 0.047 & 9.45 & $0.00 * *$ & 0.046 & 0.143 \\
\hline Consensus $\rightarrow$ Employee affective commitment & 0.256 & 0.087 & 2.94 & $0.001 * *$ & 0.102 & 0.253 \\
\hline $\begin{array}{l}\text { Line Manager's AMO } \rightarrow \text { Employee affective } \\
\text { commitment }\end{array}$ & 0.439 & 0.055 & 7.98 & $0.00 * *$ & 0.109 & 0.134 \\
\hline Ability Enhancing HPWPs $\rightarrow$ Line Manager's AMO & 0.172 & 0.035 & 4.91 & $0.038 *$ & 0.004 & 0.15 \\
\hline Motivation Focusing HPWPs $\rightarrow$ Line Manager's AMO & 0.196 & 0.047 & 4.17 & $0.00 * *$ & 0.312 & 0.51 \\
\hline Opportunity Creating HPWPs $\rightarrow$ Line Manager's AMO & 0.221 & 0.048 & 4.60 & $0.00 * *$ & 0.328 & 0.529 \\
\hline $\begin{array}{l}\text { Ability Enhancing HPWP } \rightarrow \text { Line Manager's AMO } \rightarrow \\
\text { Employee affective commitment }\end{array}$ & 0.212 & 0.039 & 5.44 & $0.024 *$ & 0.025 & 0.090 \\
\hline $\begin{array}{l}\text { Motivation Focusing HPWPs } \rightarrow \text { Line Manager's AMO } \\
\rightarrow \text { Employee affective commitment }\end{array}$ & 0.192 & 0.058 & 3.31 & $0.002 * *$ & 0.011 & 0.060 \\
\hline $\begin{array}{l}\text { Opportunity Creating HPWPs } \rightarrow \text { Line Manager's AMO } \\
\rightarrow \text { Employee affective commitment }\end{array}$ & 0.108 & 0.059 & 1.83 & $0.006^{*}$ & 0.114 & 0.282 \\
\hline Distinctiveness $\rightarrow$ Line Manager's AMO & 0.089 & 0.039 & 2.28 & $0.024 *$ & 0.011 & 0.165 \\
\hline Consistency $\rightarrow$ Line Manager's AMO & 0.186 & 0.06 & 3.11 & $0.002 * *$ & 0.066 & 0.292 \\
\hline Consensus $\rightarrow$ Line Manager's AMO & 0.064 & 0.06 & 2.72 & $0.006^{* *}$ & 0.044 & 0.274 \\
\hline $\begin{array}{l}\text { Distinctive } \rightarrow \text { Line Manager's AMO } \rightarrow \text { Employee } \\
\text { affective commitment }\end{array}$ & 0.188 & 0.017 & 5.081 & .00 & 0.026 & 0.139 \\
\hline $\begin{array}{l}\text { Consistency } \rightarrow \text { Line Manager's AMO } \rightarrow \text { Employee } \\
\text { affective commitment }\end{array}$ & 0.117 & 0.011 & 10.63 & $0.032 *$ & 0.021 & 0.212 \\
\hline $\begin{array}{l}\text { Consensus } \rightarrow \text { Line Manager's AMO } \rightarrow \text { Employee } \\
\text { affective commitment }\end{array}$ & 0.017 & 0.007 & 2.428 & $0.031 *$ & 0.075 & 0.226 \\
\hline
\end{tabular}

$$
* \mathrm{p}<.05 ; * * \mathrm{p}<.01
$$

The results imply that the line manager's AMO mediates the association between HPWP and employee affective commitment. The inclusion of the line manager's AMO mediates as a mediating variable revealed that the relationship between HPWPs (AMO) and employee affective commitment was reduced though significant. The decrease suggested partial mediation. However, the bootstrap findings show that for the indirect effect almost $95 \%$ of the bias-corrected confidence intervals (CI) are above zero for all variables, which supports hypothesis 3 .

$\mathrm{H} 4$ predicted a mediating effect of the line manager's AMO in between distinctive (H4a), consistent (H4b), and consensus (H4c) features of HRM System Strength and employee affective commitment. It was expected that when adding the line manager's AMO to the analyses, this effect will become insignificant. However, the effect $(b=0.188,0.117, .017 \mathrm{p}, 0.05)$ was found significant, though reduced. This decrease suggests partial mediation. Thus, we partially confirm H4. Further, the bootstrap outcomes confirmed that the $95 \%$ bias-corrected confidence intervals (CI) for the indirect effect are above zero for all variables, thus supporting Hypotheses 4.

\section{Discussion}

Drawing from Social Exchange theory, high performance work system theory and theory of attribution, the purpose of this study was to extend the preceding literature on effects of HPWPs and HRM system on individual outcome especially in the developing country context. The direct hypothesis among HPWPs 
(AMO), HRM system strength three features, and employee affective commitment was fully confirmed. However, both the mediation hypothesis was partially supported in this study.

Previous research has forwarded the empirical evidence that HPWPs can improve employee's individual outcomes (Liao \& Chuang, 2004). In particular, the three-dimensional model AMO provided a clear theoretical basis for HPWP in a Pakistani bank. Obeidat et al. (2016), argued that AMO dimension of HPWPs help managers find the best way to maintain long-term relationships with their employees as a key goal in the growth of HPWP in organization. Ability-enhancing HPWPs create an environment, which foster the discretionary behaviors in employees, which are required in a service context.

Motivation is a factor in performing tasks or performance in order to be rewarded or to prevent distracting stimuli (Reddy et al. 2016). Motivation enhancing practices, due to focus and usefulness, is the key driver for enhancing employee performance and attitudes (Cho et al, 2012). Opportunity creating HR practices have been described as an opportunity to build an opportunity that allows employees to take part in a wide range of aspects, including knowledge sharing. The process of Sharing knowledge with others, autonomy, and staff engagement shape elements of opportunity practices (Marin-Garcia et al., 2016). So the HPWPs backed by AMO theory, provide confidence in adoption of appropriate working condition to perform effectively and increase commitment in banking industry.

Previous research has forwarded the empirical evidence that HPWPs can improve employees outcomes (Liao \& Chuang, 2004). Having the skills, knowledge, motivation, and opportunity to effectively adopt HRM practices will increase the efficiency of line managers in implementing HRM practices, a finding in line with Gilbert et al. , (2015) and Bos-Nehles et al. (2013). A number of mixed results have emerged in relation to the other issues raised in the literature. The literature accepts both the yes and no opinions on the concept that the line manager is forced into human resources work (Harris, 2001). If the policies and procedures for managers are simpler and better established, the more they will be able to implement those (Gilbert et al., 2015).

This study also focused on the employee's perception HRM system and examined the relationship between distinctiveness, consistency, and consensus of the HRM system with employee affective commitment and line manager's role as mediator between these two. This hypothesis affirms the process based understanding of the HRM system. Results of this study found similarities with the results of other studies (Cafferkey et al., 2019; Sanders \& Yang, 2016), this study also found that the three features of HRM system strength have impact on employee commitment. The distinctiveness, consistency and consensus significantly affect the employee's commitment. In addition, Pakistani people seem to be more collectivist than individualist in Pakistan's cultural context, so they respect consensus more, i.e. general agreement for top reasons. In practice, we can assume that employees are likely to feel that the organization is determined to take their needs into account.

Moreover the study found a partial mediation of the line manager's AMO in the association between employee affective commitment and HRM system strength. These results show that employee experience of line managers ability, motivation and opporunity to implement HRM practices is essential elements in their affective commitment. Moreover, based on social exchange theory our results suggest that behavior of line managers based on AMO have an important role to play in daily routine for thier staff member. So the signals employees recieve have atleast two dimensions, first one is the HRM practices implementation itself and secondly the treatment of line mangers for the employees or staff. This means that employee's ideas, interests, beliefs, and concerns about line managers in implementing HR practices are important elements in any HRM system arrangement and not simply determined only by the actual practices only designed by the policymakers of the department or organization. 


\section{Limitations of the Study}

Some of the limitations of this study are acknowledged here. First, this study only examined a single level of employees so it can be done in multilevel settings as well. Secondly, this study is based on crosssectional data and limits the possibility of causation and reverse causation too. The sample of this study included banking service industry only, though these findings also support the extant HR research hypothesis in service context.

\section{Future Research}

The design of this study is to identify employee affective commitment in banks, keeping in view the role of line manager AMO in implementing HRM practices. Future studies can examine the individual behavioral and attitudinal impact of this mediating mechanism on other performance outcomes. Future studies can examine other mediating mechanism like, perception of different occupational group, leadership style, HRD climate and culture impact on employees outcomes etc. Moreover, dyadic or experimental design study can be conducted to further explore the insights. Future studies can also examine the possible impact of age, gender, and organizational type as moderator, beacuse these variables can have impact on employees affective commitment, e.g with age experience increases and also effect the perfromance of employees and theor commitment too (Fried et al., 2008). Like wise gender and organization type also have been found to effect the supervisory relationship (Fried et al., 2008). Multilevel phenomenon can also be studies in future while considering both unit/branch level and individual level performance outcomes in same study. Future studies can also utilize longitudinal data to further explore the causation and reverse causation. As already mentioned about the single industry limitations, future studies can re-examine this model in other service sector for comparison and more generalizability.

\section{Implications}

This study provides several implications for management practices in service organization. Besides, investigating the direct link between the HPWPs-employee outcome, this study extends past work that has previously concentrated on job satisfaction, service-oriented activities, and social exchange and focuses on implementation of the line manager's AMO as a mediator. This also encourages the organization to betterequipped line managers to get maximum benefits from the investment made in developing the HPWPs, especially in developing countries like Pakistan. Similarly, line managers should be aware of fact that employees have different capabilities in response to same HRM system signals. Thus line mangers should share consistent HRM messages either through same or different communication channels.

\section{References}

Afiouni, F. (2007). Human Resource Management and Strategy in the Lebanese Banking sector: Is there a fit. Journal of American Academy of Business, 12(1), 63-69.

Ahmed, M. F., \& Shin, H. K. (2019). An Empirical Study on HRM Practices for Organizational Performance in Bangladesh Banking Industry. Logos Management Research, 17(3), 49-76.

Aktar, A. (2018). Soft HRM practices, organizational commitment, work-related support and employee engagement in Bangladesh banking sector (Doctoral dissertation, Universiti Utara Malaysia).

Alkhazali, Z. (2020). Empowerment, HRM practices and organizational performance: a case study of Jordanian commercial banks. Entrepreneurship and Sustainability Issues, 7(4), 2991-3000.

Allen, N. J., \& Meyer, J. P. (1990). The measurement and antecedents of affective, continuance and normative commitment to the organization. Journal of occupational psychology, 63(1), 1-18.

Al-Zahrani, A. A., \& Almazari, A. A. (2014). The impact of affective human resources management practices on the financial performance of the Saudi banks. Review of Integrative Business and Economics Research, 3(1), 327. 
Andersén, J., \& Andersén, A. (2019). High-performance work systems (HPWS) appreciated by everyone? The role of management position and gender on the relationship between HPWS and affective commitment'. Employee Relations: The International Journal.

Azmi, F. T. (2010). Devolution of HRM and organizational performance: evidence from India. International Journal of Commerce and Management.

Bayo-Moriones, A., \& Bello-Pindado, A. (2021). Differences in the impact of AMO bundles of line managers and frontline workers on the performance of manufacturing firms. Academia Revista Latinoamericana de Administración.

Bhatti, K. K., \& Qureshi, T. M. (2007). Impact of employee participation on job satisfaction, employee commitment and employee productivity. International Review of Business Research Papers, 3(2), 5468.

Björkman, I., \& Gooderham, P. N. (2012). International human resource management. In research and institutional theory. In Handbook of Research in International Human Resource Management. Second Edition. Edward Elgar Publishing.

Blau, M. P. (1964). Exchange and Power in Social Life. Wiley.

Boselie, P. (2010). High performance work practices in the health care sector: a Dutch case study. International Journal of Manpower.

Bos-Nehles, A. C., Van Riemsdijk, M. J., \& Kees Looise, J. (2013). Employee perceptions of line management performance: applying the AMO theory to explain the effectiveness of line managers' HRM implementation. Human resource management, 52(6), 861-877.

Bos-Nehles, A., \& Bondarouk, T. (2019). HRM Implementation Effectiveness in the International Arena: A Multi-Level and Multi-Actor Perspective. In 75th Academy of Management Annual Meeting.

Bowen, D. E., \& Ostroff, C. (2004). Understanding HRM-firm performance linkages: The role of the 'strength' of the HRM system. Academy of Management Review, 29(2), 203-221.

Boxall, P., Ang, S. H., \& Bartram, T. (2011). Analysing the 'Black Box' of HRM: Uncovering HR Goals, Mediators, and Outcomes in a Standardized Service. Environment, 48(7), 1504-1532.

Cafferkey, K. (2019). Perceptions of HRM system strength and affective commitment: the role of human relations and internal process climate. The International Journal of Human Resource Management, 30(21), 3026-3048.

Chi, F. (2019). Industrial Change as a Turning Point from Industry Orientation to Service Orientation. In Winning at the Turning Point (pp. 21-86). Palgrave Macmillan.

Cho, Y. J., \& Perry, J. L. (2012). Intrinsic motivation and employee attitudes: Role of managerial trustworthiness, goal directedness, and extrinsic reward expectancy. Review of Public Personnel Administration, 32(4), 382-406.

Chompukum, P. (2012). Performance management effectiveness in Thai banking industry: a look from performers and a role of interactional justice. Journal of International Business and Cultural Studies, 6,1 .

CHUANG, C. H., \& Liao, H. U. I. (2010). Strategic human resource management in service context: Taking care of business by taking care of employees and customers. Personnel Psychology, 63(1), 153-196.

Cole, M. S., Schaninger, W. S., \& Harris, S. G. (2002). The workplace social exchange network: A multilevel, conceptual examination. Group and Organisation Management, 27(1), 142.

Conway, E., \& Monks, K. (2010). The devolution of HRM to middle managers in the Irish health service. Personnel Review.

Dany, F., Guedri, Z., \& Hatt, F. (2008). New insights into the link between HRM integration and organizational performance: the moderating role of influence distribution between HRM specialists and line managers. The International Journal of Human Resource Management, 19(11), 2095-2112.

Dayarathna, N. W. K. D. K. (2019). Walk or Talk? The Effect of High Performance Work System Strength on Organizational Effectiveness in Selected Banks in Sri Lanka. Sri Lankan Journal of Human Resource Management, 9(1). 
Delmotte, J., De Winne, S., \& Sels, L. (2012). Toward an assessment of perceived HRM system strength: scale development and validation. The International Journal of Human Resource Management, 23(7), 1481-1506.

Fried, Y., Shirom, A., Gilboa, S., \& Cooper, C. L. (2008). The mediating effects of job satisfaction and propensity to leave on role stress-job performance relationships: Combining meta-analysis and structural equation modeling. International Journal of Stress Management, 15(4), 305.

Galbreath, J., \& Shum, P. (2012). Do customer satisfaction and reputation mediate the CSR-FP link? Evidence from Australia. Australian journal of management, 37(2), 211-229.

Gardner, T. M., Wright, P. M., \& Moynihan, L. M. (2011). The impact of motivation, empowerment, and skill-enhancing practices on aggregate voluntary turnover: The mediating effect of collective affective commitment. Personnel psychology, 64(2), 315-350.

Gittell, J. H. (2001). Supervisory span, relational coordination and flight departure performance: A reassessment of postbureaucracy theory. Organization Science, 12(4), 468-483.

Guay, F., Vallerand, R. J., \& Blanchard, C. (2000). On the assessment of situational intrinsic and extrinsic motivation: The Situational Motivation Scale (SIMS). Motivation and Emotion, 24(3), 175-213.

Harris, L., Doughty, D., \& Kirk, S. (2002). The devolution of HR responsibilities - perspectives from the UK's public sector. Jnl Euro Industrial Training, 26(5), 218-229.

Heffernan, M., \& Dundon, T. (2016). Cross-level effects of high-performance work systems (HPWS) and employee well-being: the mediating effect of organisational justice. Human Resource Management Journal, 26(2), 211-231.

Hope, K. (2006). Pay packages need line manager input.

Hussain, N., \& Shahzad, B. (2014). Effect of direct participation on perceived organizational performance: A case study of banking sector of Pakistan. Strategies, 6(7).

Jiang, J., Wang, S., \& Zhao, S. (2012). Does HRM facilitate employee creativity and organisational innovation? A study of Chinese firms. The International Journal of Human Resource Management, 23(19), 4025-4047.

Karman, A. (2020). Understanding sustainable human resource management-organisational value linkages: The strength of the SHRM system. Human Systems Management, 39(1), 51-68.

Kehoe, R. R., \& Wright, P. M. (2013). The impact of high-performance human resource practices on employees' attitudes and behaviors. Journal of Management, 39(2), 366-391.

Kelley, H. H. (1973). The processes of causal attribution. American Psychologist, 28(2), 107.

Kepes, S., Delery, J. E., \& Gupta, N. (2008). Strategic human resource management: a systems perspective. Amproc, 2008(1), 1-6.

Khan, Z., Ferguson, D., \& Pérez, A. (2015). Customer responses to CSR in the Pakistani banking industry. International Journal of Bank Marketing.

Khilji, B. A. (2010). The Impact of Recent Financial Recession on the Banking sector of Pakistan.

Kinnie, N., \& Swart, J. (2006). The link between HR practices and strategic renewal in creative organizations: organizational learning and knowledge related performance.

Kroon, B., Van de Voorde, K., \& Van Veldhoven, M. J. P. M. (2009). Cross-level effects of high-performance work practices on burnout: Two counteracting mediating mechanisms compared. Personnel Review.

Larsen, H. H., \& Brewster, C. (2003). Line management responsibility for HRM: what is happening in Europe? Employee relations.

Lepak, D. P. (2006). A conceptual review of human resource management systems in strategic human resource management research. Research in Personnel and Human Resources Management, 25(1), 217-271.

Li, X., Sanders, K., \& Frenkel, S. (2012). How leader-member exchange, work engagement and HRM consistency explain Chinese luxury hotel employees'. Job Performance. International Journal of Hospitality Management, 31(4), 1059-1066.

Liao, H., \& Chuang, A. (2004). A multilevel investigation of factors influencing employee service performance and customer outcomes. Academy of Management journal, 47(1), 41-58. 
Liu, L. Y., \& Pan, F. (2007). The implementation of Activity-Based Costing in China: An innovation action research approach. The British Accounting Review, 39(3), 249-264.

Marin-Garcia, J. A., \& Tomas, J. M. (2016). Deconstructing AMO framework: A systematic review. Intangible Capital, 12(4), 1040-1087.

Ng, T. W., \& Feldman, D. C. (2011). Affective organizational commitment and citizenship behavior: Linear and non-linear moderating effects of organizational tenure. Journal of Vocational Behavior, 79(2), 528-537.

Obeidat, S. M., Mitchell, R., \& Bray, M. (2016). The link between high performance work practices and organizational performance. Employee Relations.

Ostroff, C., \& Bowen, D. E. (2016). Reflections on the 2014 decade award: Is there strength in the construct of HR system strength? Academy of Management Review, 41(2), 196-214.

Parker-Wilkins, V. (2006). Business impact of executive coaching: demonstrating monetary value. Industrial and Commercial Training.

Perry, E. L., \& Kulik, C. T. (2008). The devolution of HR to the line: Implications for perceptions of people management effectiveness. The International Journal of Human Resource Management, 19(2), 262-273.

Podsakoff, P. M., MacKenzie, S. B., Lee, J. Y., \& Podsakoff, N. P. (2003). Common method biases in behavioral research: a critical review of the literature and recommended remedies. Journal of applied psychology, 88(5), 879.

Reddy, L. F., Llerena, K., \& Kern, R. S. (2016). Predictors of employment in schizophrenia: the importance of intrinsic and extrinsic motivation. Schizophrenia Research, 176(2-3), 462-466.

Reilly, R. R., \& Chao, G. T. (1982). Validity and fairness of some alternative employee selection procedures 1. Personnel. Psychology, 35(1), 1-62.

Renwick, D. (2003). Line manager involvement in HRM: an inside view. Employee Relations.

Rimi, N. N. (2017). The role of devolution in HR-line manager collaboration and HRM effectiveness relationship: A study of private commercial banks in Bangladesh. Global Business and Organizational Excellence, 36(4), 43-51.

Sanders, K., \& Yang, H. (2016). The HRM process approach: The influence of employees' attribution to explain the HRM-performance relationship. Human Resource Management, 55(2), 201-217.

Sanders, K., Dorenbosch, L., \& de Reuver, R. (2008). The impact of individual and shared employee perceptions of HRM on affective commitment. Personnel Review.

Schyns, B., \& Von Collani, G. (2002). A new occupational self-efficacy scale and its relation to personality constructs and organizational variables. European Journal of Work and Organizational Psychology, 11(2), 219-241.

Shin, D. (2020). HRM systems and employee affective commitment: the role of employee gender. Gender in Management: An International Journal.

Trullen, J. (2016). The HR department's contribution to line managers' effective implementation of HR practices. Human Resource Management Journal, 26(4), 449-470.

Van De Voorde, K., Paauwe, J., \& Van Veldhoven, M. (2012). Employee well-being and the HRMorganisational performance relationship: A review of quantitative studies. International Journal of Management Reviews, 14(4), 391.

Williams, L. J., Hartman, N., \& Cavazotte, F. (2010). Method variance and marker variables: A review and comprehensive CFA marker technique. Organizational research methods, 13(3), 477-514. 